Neth. J. PI. Path. 95 (1989) 214-224

\title{
Modelling short-term effects of sulphur dioxide. 2. Quantification of biochemical characteristics determining the effect of $\mathrm{SO}_{2}$ on photosynthesis of leaves
}

\section{M.J. KROPFF}

Department of Theoretical Production Ecology, Wageningen Agricultural University, P.O. Box 430, $6700 \mathrm{AK}$ Wageningen, the Netherlands

Accepted 22 March 1989

\begin{abstract}
A summary version of a model for the $\mathrm{SO}_{2}$ flux into leaves and effects of $\mathrm{SO}_{2}$ on the rate of photosynthesis (Kropff, 1989) was used to analyse experimental data on the effects of $\mathrm{SO}_{2}$ on the rate of photosynthesis with standard statistical techniques. Values for the two key parameters of the model, a sensitivity parameter relating intracellular $\mathrm{S}(\mathrm{IV})$ concentration $\left(\mathrm{SO}_{2}\right.$, bisulphite and sulphite) to photosynthetic reduction, and a time coefficient for $\mathrm{S}(\mathrm{IV})$ oxidation, were estimated from data on photosynthesis during fumigation and subsequent recovery period, by combined non-linear regression of both equations.

The pattern of rapid photosynthetic reduction by $\mathrm{SO}_{2}$ and rapid recovery following fumigation was accurately described with the model for several data sets. Parameter estimates agree very well with experimentally determined values. It is concluded that differences in photosynthetic sensitivity of plants are mainly due to differences in the time coefficient for sulphite oxidation. Variation in leaf thickness may also have contributed to the differences in sensitivity. This approach can be used to parameterize the model for short-term effects of $\mathrm{SO}_{2}$ on leaf photosynthesis for specific species and environmental conditions from easily obtained data.
\end{abstract}

Additional keywords: stomatal behaviour, simulation model, sulphur metabolism, pollution.

\section{Introduction}

A model was presented earlier, simulating $\mathrm{SO}_{2}$ flux from the atmosphere into leaves and the effects of toxic $\mathrm{SO}_{2}$ metabolites on the rate of photosynthesis and on stomatal resistance (Kropff, 1989). The model contains two key parameters, a sensitivity parameter relating photosynthetic reduction to intracellular S(IV)* concentration, and a time coefficient for S(IV) oxidation determining the rate of S(IV) removal to the less toxic sulphate. The sensitivity parameter was derived from experimental data on photosynthetic reduction in relation to the intracellular S(IV) concentration from Sakaki and Kondo (1985) who used isolated protoplasts and chloroplasts of Vicia faba L., and Alscher et al. (1987) who studied the effects of $\mathrm{SO}_{2}$ exposure on two cultivars of Pisum sativum L. Other data sets on both effects on photosynthesis and S(IV) concent rations were not available

* $\mathrm{S}(\mathrm{IV})=\left[\mathrm{SO}_{2}\right]_{\mathrm{aq}}+\left[\mathrm{HSO}_{3}^{-}\right]+\left[\mathrm{SO}_{3}^{2-}\right]$ 
in literature. Surprisingly, the same relationship between reduction in the rate of photosynthesis and internal sulphite concentration was observed for both data sets (Kropff, 1989). Especially the results of Alscher et al. (1987) suggest that differences in sensitivity for $\mathrm{SO}_{2}$ between plants is not based on differences in the sensitivity of photosynthesis to internal S(IV). Instead, they suggest that these differences are primarily based on the capacity of leaves to remove the toxic S(IV) by oxidation, or on differences in leaf thickness, since it determines the internal concentration at a given $\mathrm{SO}_{2}$ flux density. The time coefficient for S(IV) oxidation varies strongly between species and cultivars (Miller and Xerikos, 1979; Alscher et al., 1987). Rothermel and Alscher (1985) observed that the rate of S(IV) oxidation strongly depended on the light intensity, indicating that environmental conditions may influence the rate of S(IV) oxidation.

Quantification of the relationship of biochemical parameters to environmental factors is essential for the prediction of $\mathrm{SO}_{2}$ uptake by leaf canopies and effects on canopy photosynthesis, using crop growth models extended with submodels for the effects of $\mathrm{SO}_{2}$. Such combination models may help to elucidate and predict the effects of $\mathrm{SO}_{2}$ on crops and vegetation over an entire growing period.

For experimental determination of $\mathrm{S}$ (IV) in plants during the exposure of leaves to realistic $\mathrm{SO}_{2}$ concentrations $\left(<200 \mu \mathrm{g} \mathrm{SO}_{2} \mathrm{~m}^{-3}\right)$, biochemical methods are needed to detect very low $\mathrm{S}(\mathrm{IV})$ concentrations in leaf tissue $\left[<0.05 \mathrm{mmol} \mathrm{S(IV)} \mathrm{l}^{-1}\right]$ (Kropff, 1989; Huber et al., 1987). However, the detection limit is about $0.04 \mathrm{mmol} S(I V) \mathrm{l}^{-1}$ (Huber et al., 1987) and experimental determination in leaf tissue is extremely difficult because S(IV) quickly oxidizes to sulphate.

In order to gain more insight in the quantitative values of these two parameters, the model presented in a preceding paper (Kropff, 1989) was fitted to experimental data on the short-term effects of $\mathrm{SO}_{2}$ on photosynthesis of various species.

\section{Materials and methods}

\section{Theory}

Determining biochemical characteristics from the time course of the rate of photosynthesis during exposure of a leaf to $\mathrm{SO}_{2}$ and subsequent recovery. The $\mathrm{SO}_{2}$ flux into the leaf, the sulphur balance in the leaf and the effects of toxic $\mathrm{SO}_{2}$ metabolites on photosynthesis in their simplest form can be described by four equations. A detailed description of the backgrounds is given by Kropff (1989). The sum of resistances to $\mathrm{CO}_{2}$ (consisting of the stomatal and boundary layer resistance $r$ in s $\mathrm{m}^{-1}$ ) can be derived from the rate of photosynthesis $\left(P, \mathrm{~g} \mathrm{CO}_{2} \mathrm{~m}^{2} \mathrm{~s}{ }^{\prime}\right)$ and the difference between ambient and internal $\mathrm{CO}_{2}$ concentrations $\left(C_{\mathrm{a}}-C_{\mathrm{i}}, \mathrm{g} \mathrm{CO}_{2} \mathrm{~m}^{-3}\right)$, which tends to be constant at a given $\mathrm{CO}_{2}$ concentration, even during $\mathrm{SO}_{2}$ exposure (Kropff, 1987):

$$
r=\frac{C_{\mathrm{a}}-C_{\mathrm{i}}}{P}
$$

The $\mathrm{SO}_{2}$ flux into the leaf $\left(F, \mathrm{mmol} \mathrm{SO}_{2} \mathrm{~m}^{-2} \mathrm{~s}^{-1}\right)$ can be calculated from the ambient $\mathrm{SO}_{2}$ concentration ( $\mathrm{mmol} \mathrm{SO}_{2} \mathrm{~m}^{-3}$ ) and the leaf resistance for $\mathrm{SO}_{2}$ (ca. $1.2 r$ for $\mathrm{CO}_{2}$ ), assuming the internal $\mathrm{SO}_{2}$ concentration to be 0 (Black and Unsworth, 1979; Carlson, 1983; Kropff, 1989): 


$$
F=\frac{S_{\mathrm{a}}}{1.2 r}
$$

The change in the internal S(IV) (mmol S(IV) $1^{-1}$ ) depends on the $\mathrm{SO}_{2}$ flux into the leaf and rate of S(IV) removal by oxidation of S(IV) to the less toxic sulphate:

$$
\frac{\mathrm{dS}(\mathrm{IV})}{\mathrm{d} t}=\frac{F}{d}-\frac{\mathrm{S}(\mathrm{IV})}{\tau_{2}}
$$

where $\tau_{2}$ is the time coefficient (s) for $\mathrm{S}(\mathrm{IV})$ oxidation (first order reaction) and $d$ is the leaf thickness $(\mathrm{mm})$. The effects of internal S(IV) on the rate of photosynthesis can be described with a linear relation of S(IV) concentrations up to $0.8 \mathrm{mmol}$ S(IV) $1^{-1}$ (Kropff, 1989), or reduction in the rate of photosynthesis of less than $60 \%$ (Kropff, 1989):

$$
P=P_{0}(1-k \mathrm{~S}(\mathrm{IV}))
$$

$P_{0}$ denotes the rate of photosynthesis before fumigation, $P$ the actual rate of photosynthesis and the parameter $k$ expresses the sensitivity of the rate of photosynthesis of the S(IV) concentration in [mmol S(IV)I '] ' or in [mmol S(IV) $\left.\mathrm{m}^{-2}\right]^{-1}$, when leaf thickness is not known.

Combining these four equations gives an expression for the first derivative of the $\mathrm{S}(\mathrm{IV})$ concentration with respect to time:

$$
\frac{\mathrm{dS}(\mathrm{IV})}{\mathrm{d} t}=\frac{S_{\mathrm{a}} P_{0}}{1.2\left(C_{\mathrm{a}}-C_{\mathrm{i}}\right) d}-\left(\left(\frac{S_{\mathrm{a}} P_{0} k}{1.2\left(C_{\mathrm{a}}-C_{\mathrm{i}}\right) d}+\frac{1}{\tau_{2}}\right) \mathrm{S}(\mathrm{IV})\right] ; t<t_{\mathrm{e}}
$$

where $t_{\mathrm{e}}$ is the moment at which fumigation is stopped. This equation can be abbreviated by introducing another time coefficient $\left(\tau_{1}, s\right)$ :

$$
\tau_{1}=\frac{1.2\left(C_{\mathrm{a}}-C_{\mathrm{i}}\right) d}{S_{\mathrm{a}} P_{0} k}
$$

Eqn 5 then becomes:

$$
\frac{\mathrm{dS}(\mathrm{IV})}{\mathrm{d} t}=\frac{1}{\tau_{1} k}-\left(\frac{1}{\tau_{1}}+\frac{1}{\tau_{2}}\right) \mathrm{S}(\mathrm{IV}) \quad ; \quad t<t_{\mathrm{c}}
$$

Eqn 7 can be analytically solved (with an initial S(IV) concentration of 0 ) giving an expression for the time course of $\mathrm{S}(\mathrm{IV})$ during exposure of the leaf to $\mathrm{SO}_{2}$ :

$$
\mathrm{S}(\mathrm{IV})=\frac{\frac{1}{\tau_{1} k}}{\frac{1}{\tau_{1}}+\frac{1}{\tau_{2}}}\left[1-\mathrm{e}^{-1\left(\frac{1}{\tau_{1}}+\frac{1}{\tau_{2}}\right)}\right] \quad ; \quad t<t_{\mathrm{e}}
$$


in which $t$ is the time after the start of fumigation. In combination with Eqn 4 this gives an expression for the relative rate of photosynthesis $\left(P / P_{0}, P_{0}\right.$ denotes the rate of photosynthesis before fumigation, $P$ is the actual rate of photosynthesis in time after the start of fumigation:

$$
\frac{P}{P_{0}}=\frac{\tau_{1}}{\tau_{1}+\tau_{2}}+\frac{\tau_{2}}{\tau_{1}+\tau_{2}} \mathrm{e}^{-1\left(\frac{\tau_{1}+\tau_{2}}{\tau_{1} \tau_{2}}\right)} \quad ; \quad t<t_{\mathrm{e}}
$$

When $\mathrm{SO}_{2}$ exposure is terminated, another relationship for the rate of photosynthesis has to be used. Eqn 5 is much simpler in clean air since the ambient $\mathrm{SO}_{2}$ concentration is 0 :

$$
\frac{\mathrm{dS}(\mathrm{IV})}{\mathrm{d} t}=\frac{\mathrm{S}(\mathrm{IV})}{\tau_{2}} \quad ; \quad t>t_{\mathrm{e}}
$$

An expression for the S(IV) concentration can be derived from analytical solution of Eqn 10:

$$
\mathrm{S}(\mathrm{IV})=\mathrm{S}(\mathrm{IV})_{t_{\mathrm{e}}} \mathrm{e}^{-\left(\frac{t^{-} t_{\mathrm{e}}}{\tau_{2}}\right)} \quad ; \quad t>t_{\mathrm{e}}
$$

where $t_{\mathrm{e}}$ is the moment at which fumigation is stopped. Combination of Eqn 11 with Eqn 4 gives an expression for the relative rate of photosynthesis during the recovery period:

$$
\frac{P}{P_{0}}=1-\left(1-\left(\frac{P}{P_{0}}\right)_{t_{\mathrm{e}}}\right] \mathrm{e}^{-\left(\frac{t-t_{\mathrm{e}}}{T_{2}}\right)} \quad ; \quad t>t_{\mathrm{e}}
$$

where $t$ is the time since the onset of the exposure and $\left(P / P_{0}\right)_{t_{\mathrm{e}}}$ is the relative photosynthesis at the end of the exposure period. $\left(P / P_{0}\right)_{\mathrm{e}}$ can be found from Eqn 9, which results in:

$$
\frac{P}{P_{0}}=1-\left[1-\frac{\tau_{1}}{\tau_{1}-\tau_{2}}-\frac{\tau_{2}}{\tau_{1}+\tau_{2}} \mathrm{e}^{-t_{\mathrm{c}}\left(\frac{\tau_{1}+\tau_{2}}{\tau_{1} \tau_{2}}\right)}\right] \mathrm{e}^{-\left(\frac{1-t_{\mathrm{c}}}{\tau_{2}}\right)} \quad ; \quad t>t_{\mathrm{c}}
$$

Using a non-linear regression procedure ('OPTIMIZE' in GENSTAT IV, Alvey et al., 1982), the two equations (Eqns 9 and 12b) can simultaneously be fitted to experimental data in which gas exchange is measured during a fumigation period and a subsequent recovery period. This procedure gives estimated values for $\tau_{1}$ and $\tau_{2}$. From the estimated value of $\tau_{1}$ the value of the sensitivity parameter $k$ can be calculated with Eqn 6, when $P_{0}, S_{\mathrm{a}}, C_{\mathrm{a}}$ and $C_{\mathrm{i}}$ are known $\left[k\right.$ in (mmol S(IV) $\mathrm{m}^{-2}$ leaf) ${ }^{-1}$ or in (mmol $\left.\mathrm{S}(\mathrm{IV}) \mathrm{l}^{-1}\right)^{-1}$, when the leaf thickness is known].

When stomata do not respond to a reduced photosynthesis (e.g. Alscher et al., 1987), a different set of equations has to be used (see Appendix).

Neth. J. Pl. Path. 95 (1989) 
Relating biochemical parameters and the relationship between the rate of photosynthesis and $\mathrm{SO}_{2}$ uptake in equilibrium situations. The presented set of equations and parameters can be easily related to direct measurements of $\mathrm{SO}_{2}$ uptake rate and relative photosynthesis in equilibrium situations. The two important parameters $\tau_{2}$ and $k$ [( $\left.\left.\mathrm{mmol} \mathrm{S}(\mathrm{IV}) \mathrm{m}^{-2}\right)^{-1}\right]$ can be included in one expression by combining Eqn 3 (in which the change in $\mathrm{S}(\mathrm{IV})$ concentration is set to 0 , since the $\mathrm{S}(\mathrm{IV})$ concentration is stable) with Eqn 4 which relates $\mathrm{SO}_{2}$ uptake rate and the effect on relative photosynthesis:

$$
\frac{P}{P_{0}}=1-k \tau_{2} F
$$

where $F$ is the rate of $\mathrm{SO}_{2}$ uptake in $\mathrm{mmol} \mathrm{SO}_{2} \mathrm{~m}^{-2} \mathrm{~s}^{-1}$. Kropff (1987) showed that the relationship between $\mathrm{SO}_{2}$ uptake and reduction of photosynthesis in equilibrium at light saturation of Vicia faba leaves can be described by:

$$
\frac{P}{P_{0}}=1-q F
$$

where $q$ is the slope and equals $k \tau_{2}$, when $k$ is expressed in (mmol S(IV) $\left.\mathrm{m}^{-2}\right)^{-1}$.

\section{Experimental data}

Several experimental data sets on relative photosynthesis during a short fumigation period and subsequent recovery, were used to analyse model behaviour and to quantify biochemical characteristics. Bennet and Hill (1973) measured the effect of $\mathrm{SO}_{2}$ on photosynthesis of 4-8 week old barley plants (Hordeum vulgare L., cv. Trebi). The effect of 675 and $1080 \mu \mathrm{g} \mathrm{SO}_{2} \mathrm{~m}^{-3}$ was measured for two hours after the start of fumigation and a recovery period of two hours. Sij and Swanson (1974) analysed the effects of much higher $\mathrm{SO}_{2}$ concentrations (2700-13500 $\mu \mathrm{g} \mathrm{SO}_{2} \mathrm{~m}^{-3}$ ) on bean leaves (Phaseolus vulgaris $\mathrm{L}$.) for a one-hour fumigation period and a subsequent recovery period of two hours. A very extensive data set on photosynthesis of several plant species (Vicia faba L., cv. Three fold white and cv. Blaze; Lolium perenne L., cv. S23; Hordeum vulgare L., cv. Sonja; Triticum aestivum L., cv. Virtue and Brassica napus L., cv. Rafal.), influenced by a large range of $\mathrm{SO}_{2}$ concentrations $(270,540,810,1080$ and $1350 \mu \mathrm{g} \mathrm{SO}_{2} \mathrm{~m}^{-3}$ respectively) was published by Darrall (1986). The first three species were grown in the glasshouse and the second group was grown outdoors. The plants grown outdoors were much less sensitive to $\mathrm{SO}_{2}$ than plants grown in the greenhouse. Finally, a data set on leaves of Vicia faba L.cv. Minica exposed to 810 and $1600 \mu \mathrm{g}$ $\mathrm{SO}_{2} \mathrm{~m}^{-3}$ was used (Kropff and Smeets, unpublished) for methods see Kropff (1987). Absolute rates of photosynthesis before the start of fumigation $\left(P_{0}\right)$ and internal $\mathrm{CO}_{2}$ concentrations needed to calculate the sensitivity parameter $k$, were estimated when they were not reported.

\section{Results and discussion}

Determining biochemical characteristics from the time course of the rate of photosynthesis during exposure of a leaf to $\mathrm{SO}_{2}$ and subsequent recovery. The combination 
of Eqns 9 and $12 \mathrm{~b}$ was fitted to experimental data on photosynthesis during fumigation and recovery to estimate values for the parameters $\tau_{1}$ and $\tau_{2}$ can also be estimated from the rate of photosynthesis during fumigation only. However, when both the fumigation and recovery period are used, more information on model behaviour in relation to the real system is obtained and the interdependence of the estimated parameter values is reduced.

The results of fitting the model to the experimental data from Darrall (1986), Bennet and Hill (1973), Sij and Swanson (1974) and the data set with broad bean are presented in Fig. 1. The pattern of a rapid reduction after the start of the exposure and the fast recovery after the fumigation period was described very satisfactorily by the model for all data sets. Both the time course of the rate of photosynthesis during and after exposure were accurately described by the model with one set of parameters. This indicates that short-term effects can be well described on the basis of the proposed mechanism. Unreliable estimates of the parameters were determined when reductions in the rate of photosynthesis were very low $(<5 \%)$. Relative photosynthesis during the recovery period was not described correctly at very high $\mathrm{SO}_{2}$ concentrations only, indicating that mechanisms other than a reversible inhibition of photosynthesis by S(IV) played an important role as well (Vicia faba L. cv. Blaze at $1350 \mu \mathrm{g} \mathrm{SO}_{2} \mathrm{~m}^{-3}$ and Phaseolus vulgaris at $13500 \mu \mathrm{g} \mathrm{SO}_{2} \mathrm{~m}^{-3}$ ).

The estimated parameter values are given in Table 1. Since leaf thickness is unknown for the experimental data used here, $k$ expresses the relative reduction of photosynthesis per unit of S(IV) per unit leaf area, instead of per unit leaf volume. The values for $k$, are in the same range as the $0.832\left(\mathrm{mmol} \mathrm{S}(\mathrm{IV}) \mathrm{l}^{-1}\right)^{-1}$ (Kropff, 1989), determined from the measurement of Alscher et al. (1987) and Sakaki and Kondo (1985). When leaf thickness equals $0.5 \mathrm{~mm}, k$ is $1.664\left(\mathrm{mmol} \mathrm{S}(\mathrm{IV}) \mathrm{m}^{-2}\right)^{-1}$ and at $0.2 \mathrm{~mm}, k$ equals $4.16\left(\mathrm{mmol} \mathrm{S}(\mathrm{IV}) \mathrm{m}^{-2}\right)^{-1}$. This indicates that differences in the determined values of $k$ may possibly be explained on the basis of differences in leaf thickness, i.e. the Hordeum plants of Darrall (1986) were grown outside, whereas the other species were grown indoors, where plants normally have thinner leaves.

Large differences were observed in the time coefficient for S(IV) oxidation, which confirms the results of Alscher et al. (1987) that the rate of sulphite oxidation determines the sensitivity of species. The differences in sensitivity bet ween Hordeum vulgare and the other species examined by Darrall (1986) seems to be caused by large differences in the rate of S(IV) oxidation in combination with differences in leaf thickness.

This illustrates the necessity of working in well defined conditions, since both oxidation potentials of leaves and leaf thickness are determined by growth conditions. These data indicate that field-grown plants are less sensitive to air pollutants than plants grown in the greenhouse or phytotron. The time coefficient for S(IV) oxidation in some plant species (Vicia faba cv. Blaze, Lolium perenne and Phaseolus vulgaris) increases with increasing $\mathrm{SO}_{2}$ concentration, indicating an additional (irreversible) effect. The sensitivity of plants clearly increases with increasing time coefficient for $\mathrm{S}(\mathrm{IV})$ oxidation (Table 1; Fig. 1).

The estimation of the parameters from literature data is inaccurate, because only means are reported in literature, without stanard errors, and the data necessary to calculate $k$ (see Eqn 6) are rarely reported accurately. The best procedure for estimation of the parameters will be the determination of the parameters for data on individual plants, which allows the estimation of the variation in $k$ and $\tau_{2}$ in plants from Neth. J. Pl. Path. 95 (1989) 
Relative photosynthesis (\%)
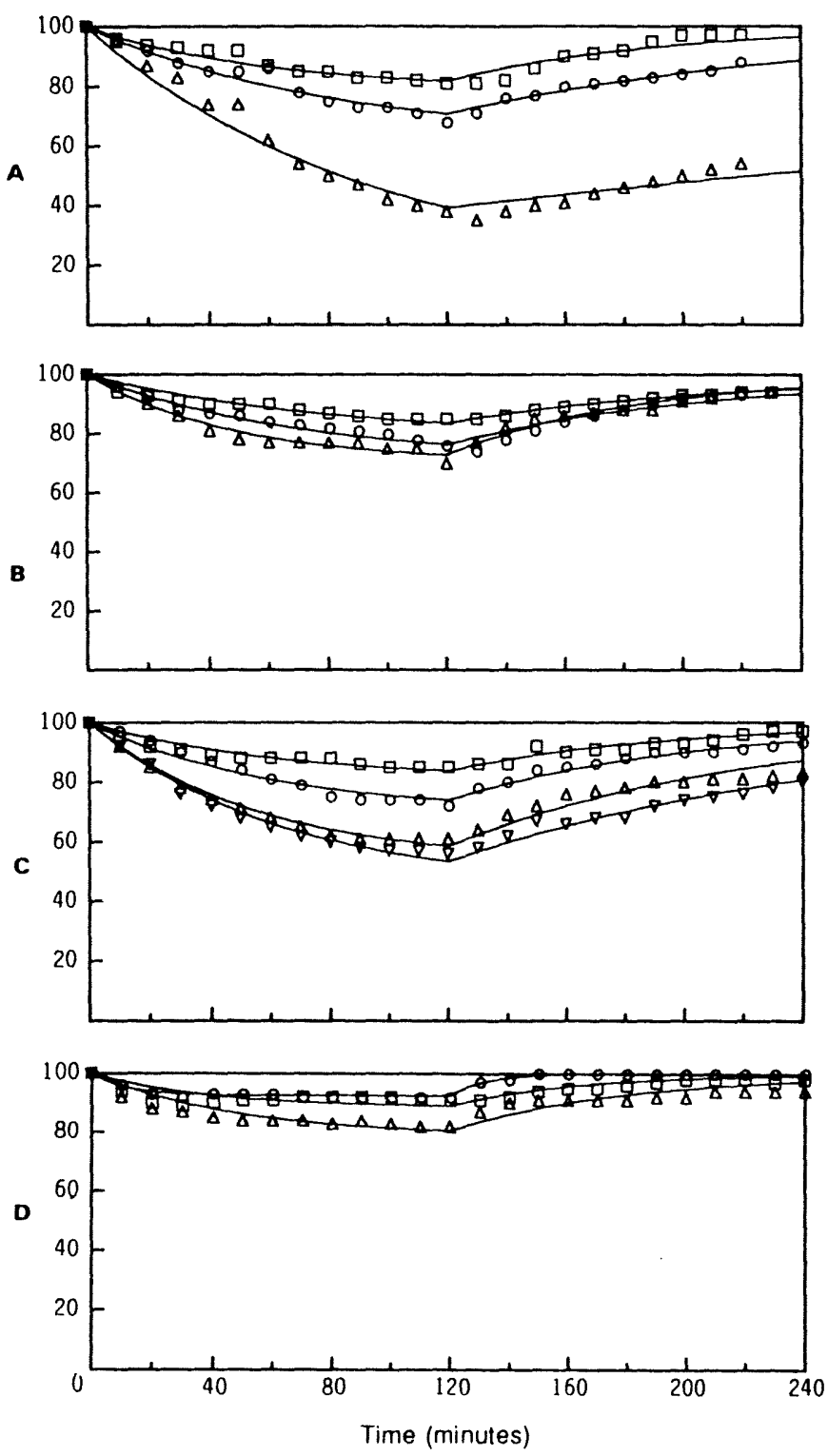

replicates. This procedure will be followed in a next paper, which deals with the effect of temperature and humidity on photosynthetic depression during $\mathrm{SO}_{2}$ exposure.

Relating biochemical parameters and the relationship between the rate of photosynthesis and $\mathrm{SO}_{2}$ uptake in equilibrium situations. The parameter values derived for broad bean (Table 1) were related to direct measurements of the $\mathrm{SO}_{2}$ uptake rate and the rate of photosynthesis with Eqns 13 and 14. The parameter values derived from 

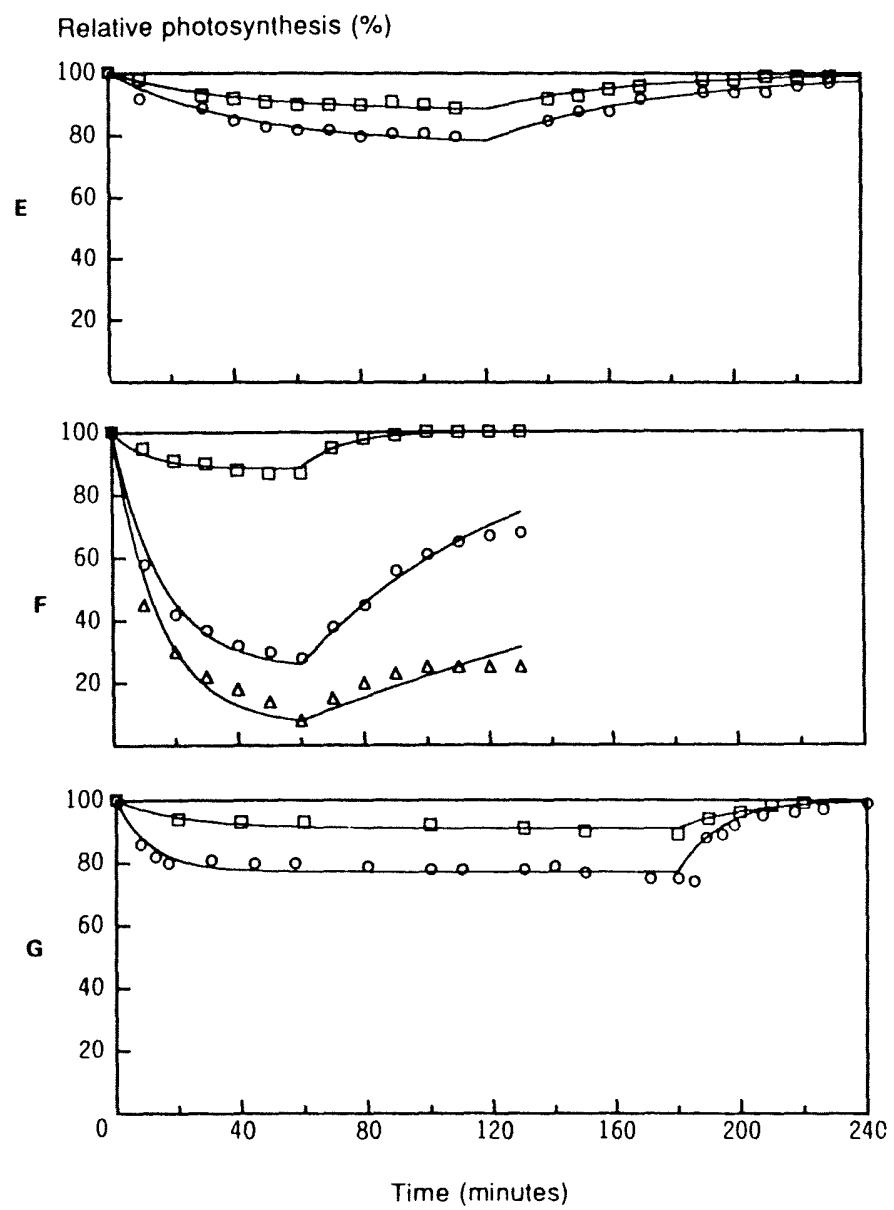

Fig. 1. Observed relative photosynthesis of single leaves during fumigation (2-3 h) and a subsequent recovery period (markers), and fitted relations with the model (lines). Parameter values are listed in Table 1. Data from Darrall, 1986:

a) Vicia faba cv. Blaze ( $810 \mu \mathrm{g} \mathrm{SO}_{2} \mathrm{~m}^{-3} ; \circ 1080 \mu \mathrm{g} \mathrm{SO}_{2} \mathrm{~m}^{-3} ; \triangle 1350 \mu \mathrm{g} \mathrm{SO}_{2} \mathrm{~m}^{-3}$ );

b) Vicia faba cv. Three fold white ( $\mathrm{a} 810 \mu \mathrm{g} \mathrm{SO}_{2} \mathrm{~m}^{-3} ; \circ 1080 \mu \mathrm{g} \mathrm{SO}_{2} \mathrm{~m}^{-3} ; \triangle 1350 \mu \mathrm{g} \mathrm{SO}_{2}$ $\mathrm{m}^{-3}$ );

c) Lolium perenne cv. S23 ( व $540 \mu \mathrm{g} \mathrm{SO}_{2} \mathrm{~m}^{-3} ; \circ 810 \mu \mathrm{g} \mathrm{SO}_{2} \mathrm{~m}^{-3} ; \triangle 1080 \mu \mathrm{g} \mathrm{SO}_{2} \mathrm{~m}^{-3} ; \nabla 1350$ $\mu \mathrm{g} \mathrm{SO} \mathrm{m}^{-3}$ );

d) Hordeum vulgare cv. Sonja ( $\square 810 \mu \mathrm{g} \mathrm{SO}_{2} \mathrm{~m}^{-3} ; \circ 1080 \mu \mathrm{g} \mathrm{SO}_{2} \mathrm{~m}^{-3} ; \Delta 1350 \mu \mathrm{g} \mathrm{SO}_{2} \mathrm{~m}^{-3}$ ). Data from Bennet and Hill, 1973;

e) Hordeum vulgare cv. Trebi ( $675 \mu \mathrm{g} \mathrm{SO}_{2} \mathrm{~m}^{-3}$; 。 $1080 \mu \mathrm{g} \mathrm{SO}_{2} \mathrm{~m}^{-3}$ ).

Data from Sij and Swanson, 1974;

f) Phaseolus vulgaris ( $2700 \mu \mathrm{g} \mathrm{SO}_{2} \mathrm{~m}^{-3} ; \circ 8700 \mu \mathrm{g} \mathrm{SO}_{2} \mathrm{~m}^{-3} ; \triangle 13500 \mu \mathrm{g} \mathrm{SO}_{2} \mathrm{~m}^{-3}$ and

g) Vicia faba cv. Minica, unpublished ( $810 \mu \mathrm{g} \mathrm{SO}_{2} \mathrm{~m}^{-3} ; \circ 1600 \mu \mathrm{g} \mathrm{SO}_{2} \mathrm{~m}^{-3}$ ). 
Table 1. Estimated values for $\tau_{1}$ and $\tau_{2}$ (minutes) with standard error and $k$, calculated from $\tau_{1}\left(\mathrm{mmol} \mathrm{S}(\mathrm{IV}) \mathrm{m}^{-2}\right)^{-1}$. $\mathrm{SO}_{2}$ concentration in $\mu \mathrm{g} \mathrm{SO} \mathrm{m}^{-3}$.

\begin{tabular}{|c|c|c|c|c|c|c|}
\hline & $\begin{array}{l}\mathrm{SO}_{2} \\
\left(\mu \mathrm{g} \mathrm{m}^{-3}\right)\end{array}$ & $\begin{array}{l}\tau_{1} \\
\text { (minutes) }\end{array}$ & $\mathrm{SE}$ & $\begin{array}{l}\tau_{2} \\
\text { (minutes) }\end{array}$ & $\mathrm{SE}$ & $\begin{array}{l}k \\
(\mathrm{mmol} \\
\left.\mathrm{S}(I V) \mathrm{m}^{-2}\right)^{-1}\end{array}$ \\
\hline $\begin{array}{l}\text { Vicia faba (cv. Blaze) } \\
\quad \text { (Darrall, 1986) }\end{array}$ & $\begin{array}{r}810 \\
1080 \\
1350\end{array}$ & $\begin{array}{l}277.2 \\
213.0 \\
110.4\end{array}$ & $\begin{array}{r}20.3 \\
9.1 \\
5.1\end{array}$ & $\begin{array}{r}72.7 \\
128.2 \\
533.9\end{array}$ & $\begin{array}{r}6.5 \\
8.6 \\
98.5\end{array}$ & $\begin{array}{l}2.1 \\
1.9 \\
3.3\end{array}$ \\
\hline $\begin{array}{c}\text { Vicia faba (cv. Three fold } \\
\text { white) (Darrall, 1986) }\end{array}$ & $\begin{array}{r}810 \\
1080 \\
1350\end{array}$ & $\begin{array}{l}367.7 \\
237.3 \\
159.1\end{array}$ & $\begin{array}{r}18.5 \\
11.8 \\
6.9\end{array}$ & $\begin{array}{l}96.5 \\
93.1 \\
66.5\end{array}$ & $\begin{array}{l}6.7 \\
6.0 \\
3.3\end{array}$ & $\begin{array}{l}1.1 \\
1.4 \\
1.7\end{array}$ \\
\hline $\begin{array}{l}\text { Lolium perenne (Darrall, } \\
\text { 1986) }\end{array}$ & $\begin{array}{r}540 \\
810 \\
1080 \\
1350\end{array}$ & $\begin{array}{l}320.9 \\
196.4 \\
117.1 \\
114.0\end{array}$ & $\begin{array}{r}19.5 \\
7.9 \\
4.8 \\
3.2\end{array}$ & $\begin{array}{r}74.9 \\
84.4 \\
101.9 \\
135.5\end{array}$ & $\begin{array}{l}5.6 \\
4.2 \\
5.1 \\
5.1\end{array}$ & $\begin{array}{l}2.1 \\
2.3 \\
2.9 \\
2.3\end{array}$ \\
\hline $\begin{array}{l}\text { Hordeum vulgare (1) } \\
\text { (Darrall, 1986) }\end{array}$ & $\begin{array}{r}810 \\
1080 \\
1350\end{array}$ & $\begin{array}{l}335.1 \\
150.9 \\
224.3\end{array}$ & $\begin{array}{l}60.2 \\
10.5 \\
23.9\end{array}$ & $\begin{array}{l}43.1 \\
12.7 \\
59.5\end{array}$ & $\begin{array}{l}8.8 \\
0.9 \\
7.4\end{array}$ & $\begin{array}{l}1.2 \\
2.2 \\
1.2\end{array}$ \\
\hline $\begin{array}{l}\text { Hordeum vulgare (2) } \\
\quad \text { (Bennet and Hill, 1973) }\end{array}$ & $\begin{array}{r}675 \\
1080\end{array}$ & $\begin{array}{l}339.6 \\
188.3\end{array}$ & $\begin{array}{r}16.2 \\
8.6\end{array}$ & $\begin{array}{l}46.0 \\
56.1\end{array}$ & $\begin{array}{l}2.5 \\
2.9\end{array}$ & $\begin{array}{l}2.1 \\
2.3\end{array}$ \\
\hline $\begin{array}{l}\text { Phaseolus vulgaris } \\
\quad \text { (Sij and Swanson, 1974) }\end{array}$ & $\begin{array}{r}2700 \\
8100 \\
13500\end{array}$ & $\begin{array}{l}99.1 \\
20.7 \\
15.9\end{array}$ & $\begin{array}{l}11.4 \\
1.2 \\
1.32\end{array}$ & $\begin{array}{r}13.3 \\
66.1 \\
238.2\end{array}$ & $\begin{array}{r}1.6 \\
3.4 \\
26.8\end{array}$ & $\begin{array}{l}1.7 \\
2.7 \\
2.1\end{array}$ \\
\hline Vicia faba (cv. Minica) & $\begin{array}{r}810 \\
1600\end{array}$ & $\begin{array}{r}231.7 \\
48.7\end{array}$ & $\begin{array}{r}24.1 \\
5.7\end{array}$ & $\begin{array}{l}23.1 \\
14.4\end{array}$ & $\begin{array}{l}2.3 \\
1.7\end{array}$ & $\begin{array}{l}2.2 \\
2.9\end{array}$ \\
\hline
\end{tabular}

data on the rate of leaf photosynthesis during $\mathrm{SO}_{2}$ exposure (Kropff, 1989) are in close agreement with the observed relationship between the rate of photosynthesis and $\mathrm{SO}_{2}$ uptake rate after two hours of exposure. The value for $q$ was estimated to be $0.05(\mu \mathrm{g}$ $\left.\mathrm{SO}_{2} \mathrm{~m}^{-2} \mathrm{~s}^{-1}\right)^{-1}$ for this series of measurements. The values for $\tau_{2}$ and $k$ are given in Table $1\left(\tau_{2}=1380\right.$ seconds and $\left.k=2.25\left(\mathrm{mmol} \mathrm{S}(\mathrm{IV}) \mathrm{m}^{2}\right){ }^{\prime}\right)$, resulting in $\left(k \tau_{2}=\right)$ $3105\left(\mathrm{mmol} \mathrm{SO}_{2} \mathrm{~m}^{-2} \mathrm{~s}^{-1}\right)^{1}$ or $0.048\left(\mu \mathrm{g} \mathrm{SO}_{2} \mathrm{~m}^{-2} \mathrm{~s}^{-1}\right)^{-1}$. Leaf thickness was $0.4 \mathrm{~mm}$ for the plants used. The $k$ value calculated from Table $1(2.25 \times 0.4=0.915(\mathrm{mmol}$ $\left.\mathrm{S}(\mathrm{IV}) \mathrm{I}^{-1}\right)^{-1}$ is in agreement with $k$ estimated from data of Alscher et al. (1987) and Sakaki and Kondo (1985) (Kropff, 1989).

\section{Acknowledgements}

This work was supported by the Dutch Priority Programme on Acidification. I gratefully acknowledge J. de Bree for statistical advice. I am also indebted to J. Goudriaan, C.T. de Wit, M.H. Unsworth, C. Rappoldt and W. Smeets for helpful discussions and Th.A. Dueck and H.H. van Laar for comments on the manuscript. 


\section{Appendix \\ A model for the effects of $\mathrm{SO}_{2}$ on photosynthesis when stomata do not respond to a reduced photosynthesis}

When photosynthesis is depressed, but stomatal resistance remains unchanged during $\mathrm{SO}_{2}$ exposure (Alscher et al., 1987), Eqns 9 and $12 \mathrm{~b}$ cannot be used to analyse experimental data, because stomatal closure is assumed in this set of equations.

The main difference in the basic set of Eqns $1-4$ is the substitution of $P$ by $P_{0}$ in Eqn 1. Following the same procedure as described in the text, Eqn 9 then becomes:

$$
\frac{P}{P_{0}}=1-\frac{\tau_{2}}{\tau_{1}}\left(1-\mathrm{e}^{\frac{-t}{\tau_{2}}}\right) \quad ; \quad t<t_{\mathrm{e}}
$$

Eqn $12 \mathrm{a}$ remains unchanged. For Eqn $12 \mathrm{~b}$ the following expression can be derived by combination of Eqns 12a and 15:

$$
\frac{P}{P_{0}}=1-\left[\frac{\tau_{2}}{\tau_{1}}\left(1-\mathrm{e}^{\frac{-t_{\mathrm{c}}}{\tau_{2}}}\right)\right] \mathrm{e}^{-\left(\frac{t-t_{\mathrm{c}}}{\tau_{2}}\right)} \quad ; \quad t>t_{\mathrm{e}}
$$

Calculation of $k$ can be performed with Eqn 6 .

\section{Samenvatting}

Simulatie van de korte termijn effecten van zwaveldioxide. 2. Kwantificeren van biochemische karakteristieken die het effect van $\mathrm{SO}_{2}$ op de fotosynthese bepalen

Een model voor de flux van $\mathrm{SO}_{2}$ in het blad, het metabolisme van $\mathrm{SO}_{2}$ in het blad en de effecten van $\mathrm{SO}_{2}$-metabolieten op de fotosynthese (Kropff, 1989) is gebruikt om gegevens over het effect van $\mathrm{SO}_{2}$ op de fotosynthese tijdens en na een begassingsperiode te analyseren met standaard statistische technieken. De waarde voor de parameter die de relatie tussen S(IV) en fotosynthese karakteriseert en de waarde van de tijdconstante voor de S(IV)-oxidatie werden voor verschillende data-sets over het verloop van de fotosynthese tijdens en na begassing met $\mathrm{SO}_{2}$ geschat.

De snelle reductie van de fotosynthese na de start van de begassing, het stabiliseren na 1 uur en het snelle herstel na de begassing werden zeer goed met het model beschreven voor de data-sets. De waarden voor de parameters bleken vergelijkbaar met gegevens uit biochemische analyses. Verschillen in gevoeligheid tussen planten voor $\mathrm{SO}_{2}$ blijken met name te berusten op verschillen in de snelheid waarmee S(IV) wordt geoxideerd. Variatie in bladdikte kan daarnaast van belang zijn geweest. De benadering kan worden gebruikt om inzicht te krijgen in biochemische karakteristieken die de effecten van $\mathrm{SO}_{2}$ bepalen, met behulp van relatief eenvoudig te verkrijgen data-sets. 


\section{References}

Alscher, R., Bower, J.L. \& Zipfel, W., 1987. The basis for different sensitivities of photosynthesis to $\mathrm{SO}_{2}$ in two cultivars of pea. Journal of Experimental Botany 38: 99-108.

Alvey, N., Galwey, N. \& Lane, P., 1982. An introduction to Genstat. Academic Press, London, New York, $152 \mathrm{pp}$.

Bennett, J.H. \& Hill, A.C., 1973. Inhibition of apparent photosynthesis by air pollutants. Journal of Environmental Quality 2: 526-530.

Black, V.J.\& Unsworth, M.H., 1979. Resistance analysis of sulphur dioxide fluxes to Vicia faba. Nature 282: 68-69.

Carlson, R.W., 1983. The effect of $\mathrm{SO}_{2}$ on photosynthesis and leaf resistance at varying concentrations of $\mathrm{CO}_{2}$. Environmental Pollution (series A) 30: 309-321.

Darrall, N.M., 1986. The sensitivity of net photosynthesis in several plant species to short-term fumigation with sulphur dioxide. Journal of Experimental Botany 37: 1313-1322.

Huber, K., Esterbauer, H., Jäger, H.-J. \& Grill, D., 1987. Detection of sulphite in plants. Environmental Pollution (series A) 46: 127-136.

Kropff, M.J., 1987. Physiological effects of sulphur dioxide. 1. The effect of $\mathrm{SO}_{2}$ on photosynthesis and stomatal regulation of Vicia faba L. Plant, Cell and Environment 10: 753-760.

Kropff, M.J., 1989. Modelling short-term effects of sulphur dioxide. 1. A model for the flux of $\mathrm{SO}_{2}$ into leaves and effects on leaf photosynthesis. Netherlands Journal of Plant Pathology 95 (1989): 195-213.

Miller, J.E. \& Xerikos, P.B., 1979. Residence time of sulphite in $\mathrm{SO}_{2}$ 'sensitive' and 'tolerant' soybean cultivars. Environmental Pollution (series A) 18: 259-264.

Rothermel, B. \& Alscher, R., 1985. A light-enhanced metabolism of sulphite in cells of Cucumis sativus L. cotyledons. Planta 166: 105-110.

Sakaki, T. \& Kondo, N., 1985. Inhibition of photosynthesis by sulphite in mesophyll protoplasts isolated from Vicia faba L. in relation to intracellular sulphite accumulation. Plant and Cell Physiology 26: 1045-1055.

Sij, J.W. \& Swanson, C.A., 1974. Short-term kinetic studies on the inhibition of photosynthesis by sulphur dioxide. Journal of Environmental Quality 3: 103-107. 